\title{
An updated description of the montane Gymnophora lapidocola (Bezzi) (Diptera: Phoridae) that is flightless in both sexes
}

\author{
R. Henry L. DISNEY \\ Department of Zoology, University of Cambridge, Cambridge CB2 3EJ, England; e-mail: rhld2@hermes.cam.ac.uk

\begin{abstract}
Fresh material of the inadequately described male of Gymnophora lapidicola (Bezzi, 1922), which is flightless in both sexes, has allowed illustration of critical details, including correction of an error in the description of the female by Ghidini (1934). The possibility that populations on different mountains may have diverged to form separate subspecies or sibling species is raised.
\end{abstract}

Key words: Diptera, Phoridae, Gymnophora, Italy

\section{INTRODUCTION}

Many genera of Phoridae have flightless females, but normally winged males. For example Chonocephaus Wandolleck and Puliciphora Dahl. Typically the male transports the flightless female during a nuptial flight (e.g. Miller, 1979). Flightless males are known for two Afrotropical montane genera: Aptinandria Schmitz (1921) and Arrenaptenus Schmitz. Aptinandria Schmitz (1921) was described from the female only of a single species; but, although its male has not been described, it was included in a key to genera by Beyer (1965). Arrenaptenus Schmitz includes two species (Schmitz 1958, Borgmeier, 1959). Otherwise a single Palaearctic, montane species, Gymnophora lapidicola (Bezzi) has been described from Italy (Bezzi (1922), for the male and Ghidini (1934), for its female). A few males in other genera possess reduced wings but are still capable of limited, short hopping flights. For example Triphleba recidopennis Mostovski \& Disney (2002) seeks its flightless female on the surface of the snow in the mountains of Kazakhstan. The association of flightless males with mountains is interpreted as an adaptation that avoids the risk of flying males being swept off their mountain habitat by a gust of wind. Their concomitant adaptation is tolerance of low temperatures that allows them to colonise a habitat where competition and other threats are reduced.

\section{RESULTS}

\section{Gymnophora lapidicola (Bezzi)}

(Figs 1-19)

Capraephora lapidicola Bezzi, 1922: 116 (male)

Gymnophora lapidicola (Bezzi) Ghidini, 1934: 131 (female)

The recognition of this species has been problematical in that Bezzi's description, based on the pinned holotype (in the Museo Civico di Storia Naturale in Milan), included no figures. Regretfully permission to remount it on a slides was declined. In Ghidini's paper the figure of the wing rudiment is highly misleading as it portrays the leading edge of the wing as being curved (concave). Also in the museum in Milan are three pin mounted specimens collected in 1922 at Alpi biellesi (i.e. the Alps surrounding the town of Biella), 1-viii-[19]23, Capra (the collector). On of these specimens has the additional label - Lago di Lamaccia [a very small lake in the upper valley], Val Sorba, 1-viii-903, Capra. 


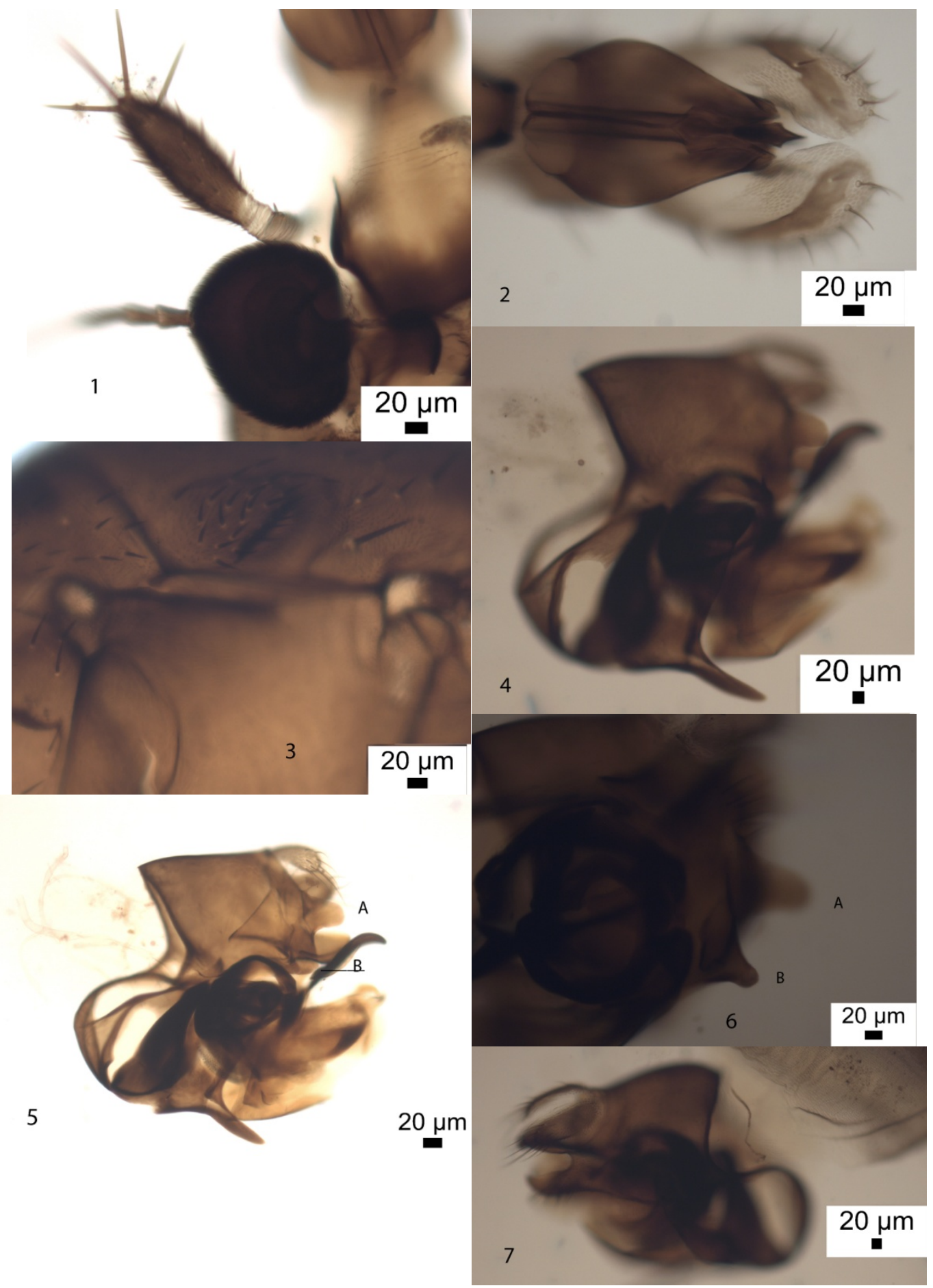

Figs 1-6. Gymnophora lapidocola male. 1 - palp and postpedicel; 2 - proboscis; 3 - notopleuron; 4-6 - left faces of hypopygium (A \& B = lobes of epandrium); 7 - right face of hypopygium. 

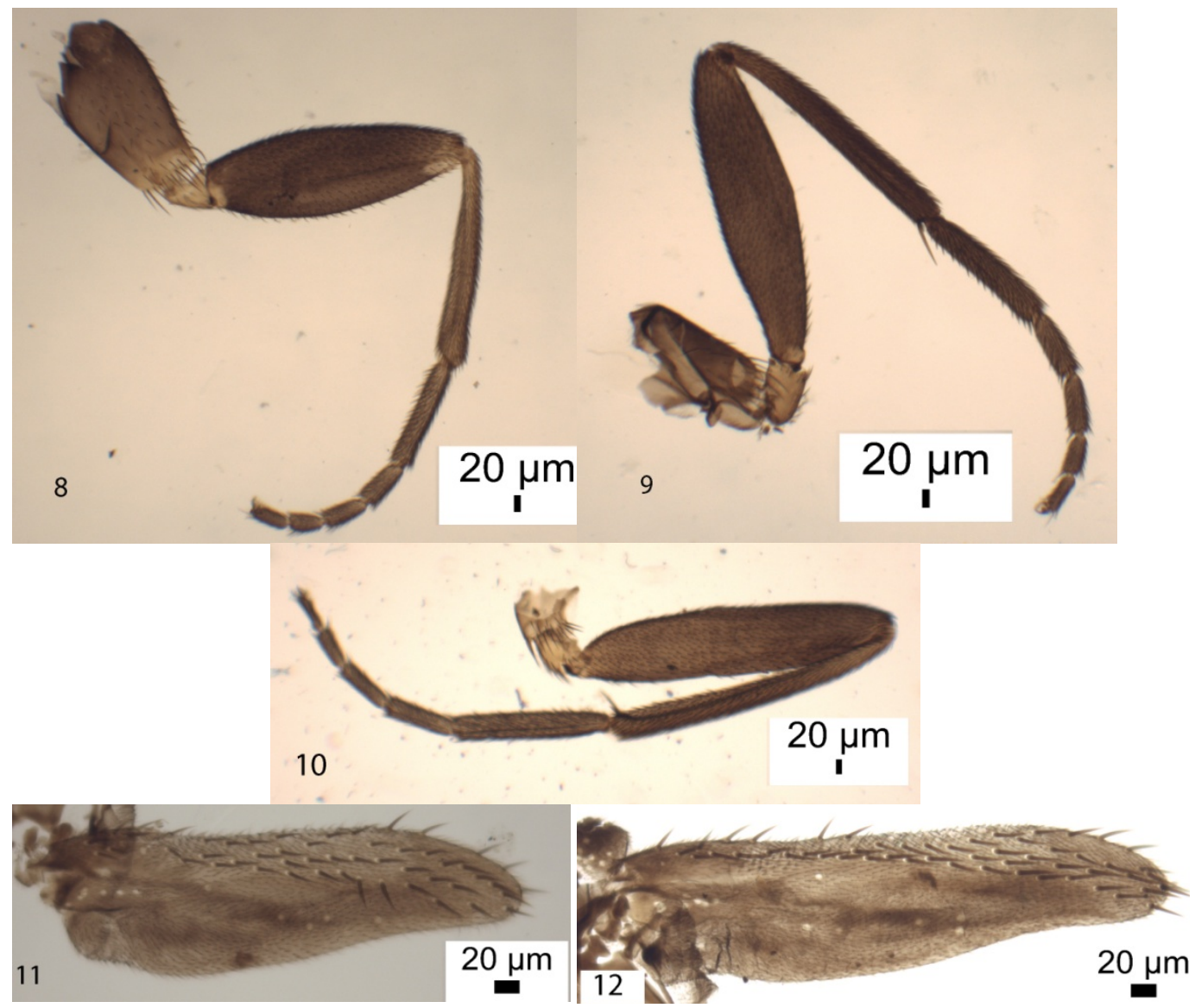

Figs 8-12. Gymnophora lapidocola male; 8 - front leg; 9 - middle leg; 10 - hind leg; 11-12 - wing rudiments of two different specimens.

Again permission to remount was declined. In one of these specimens the wing rudiment looks like in Ghidini's figure, but only because the outer half of its wing rudiment is deflected downwards. With the other two specimens the rudiments are lying flat. Critical details of these specimens and of the holotype cannot be discerned in these pinned specimens.

Erminio Piva sent me a large series of both sexes in $70 \%$ ethanol. These were collected in Italy, Veneto Province of Vicenza, Lessini Mountains, superficial subterranean habitat in a small valley at 1600m altitude, 18 Jun 2014 (leg. D. Blanco, ref.47v/vi). 10 males and 14 females have been mounted on slides in Berlese Fluid and deposited in the University of Cambridge Museum of Zoology (16-56). This new material, along with Bezzi's and Ghidini's specimens, readily runs down to G. lapidicola in the latest review of the Palaearctic species of Gymnophora (Mostovski \& Michaelovskaya, 2003) based solely on the possession of rudimentary wings. The assignment to G. lapidiciola therefore is by default. Fresh material from the type locality mounted on slides may require reassessment of this assignment, and likewise of Ghidini's assignment of the females to this species. In the meantime I illustrate critical details of the fresh sample. 

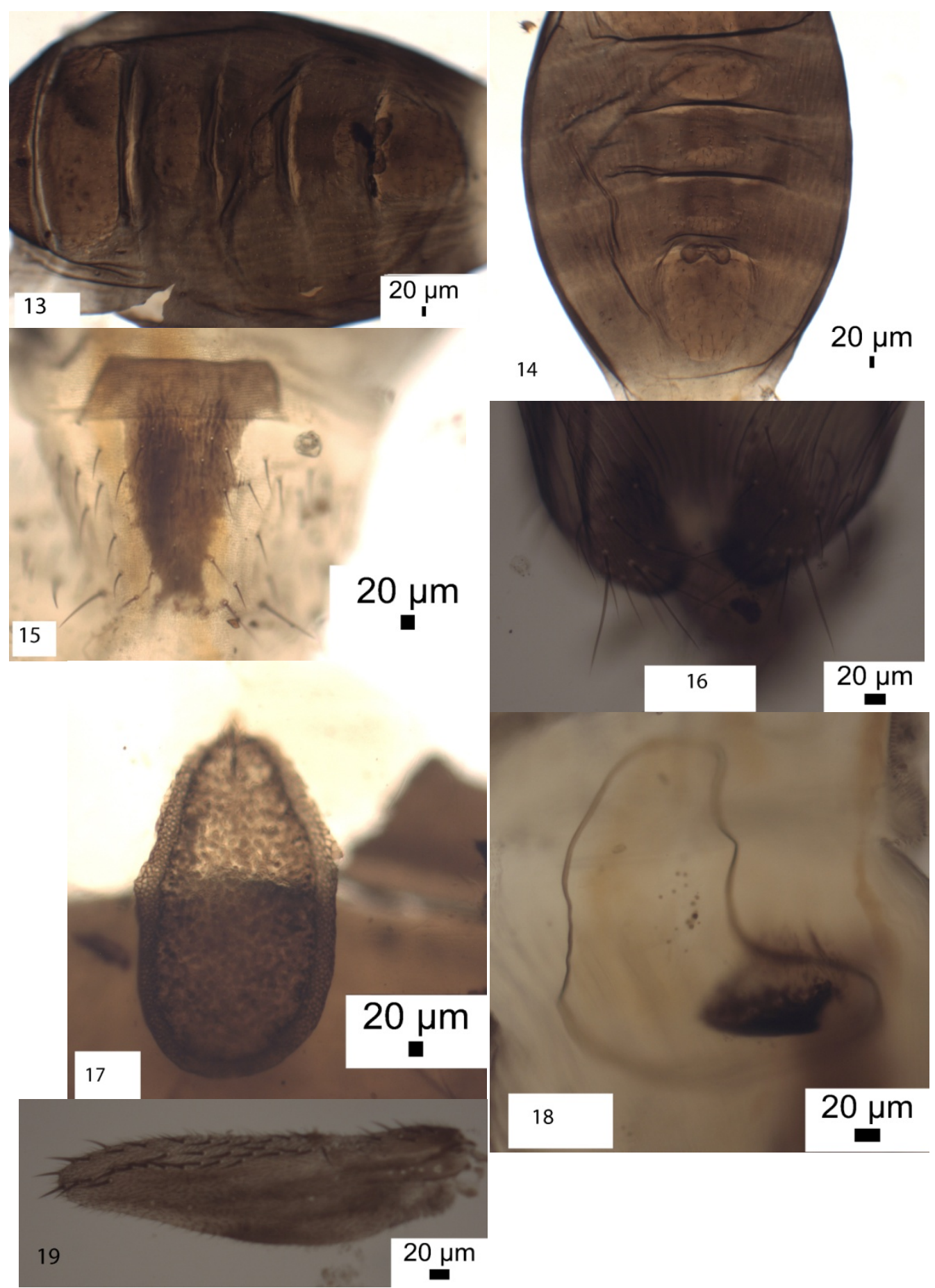

Figs 13-19. Gymnophora lapidocola female. 13-14 - abdominal tergites 2-6; 15 - tergite 7; 16 - lobes at rear of sternite 8; 17 - Dufour's crop mechanism; 18 - furca from above; 19 - wing rudiment 
Male. Postpedicels and palps as in Fig. 1. Proboscis as in Fig. 2. Notopleuron as in Fig. 3. Hypopygium as in Figs 4-7, with some variation in the posterior lobes of the left face of the epandrium (A and B in Figs 5 \& 6). Legs as in Figs 8-10. Wing rudiments as in Figs 11-12.

Female. Abdominal tergites as in Figs 13-15. Sternite 8 as in Fig. 16. Dufour's crop mechanism as in Fig. 17. Furca as in Fig. 18. Wing rudiment as in Fig. 19.

\section{DISCUSSION}

Gymnophora lapidicola was recorded from Bochetto del Croso, Val Chioblin, Biello, at about 1940 m altitude, beneath a rock, in September; and on Alpe Finestre, at about $1700 \mathrm{~m}$ and $1850 \mathrm{~m}$ altitude in July and September. Cold adapted insects are known to diapause during the cold winter months by means of polyhydric alcohols (such as glycerol) by means of which they are able to supercool (Leather et al., 1993). North of the Arctic Circle more than 60 species of Phoridae have been reported over an extensive area, but with the adults restricted to July and August and the pre-adult stages surviving the extreme low winter temperatures beneath the thick insulating blanket of snow (Disney 2013). On the tops of the mountains in Italy the temperatures are less extreme, allowing a longer season of activity by the adults. However, these peaks will in effect be cool habitat islands in a sea of a terrain at lower altitudes and subjected to less extreme cold temperatures. Flightless insects restricted to these 'island' peaks will tend to become isolated from those on other peaks in the region, with a result that they will tend to deviate from an original ancestral species leading to subspecies or sibling species each of which is confined to its own peak. This might prove to be the situation with $G$. lapidicola. If this speculation proves to be correct we can expect different sibling species to occur on different peaks in the region. To test this speculation will require close comparisons of the details illustrated in this paper with the details of samples from different peaks.

\section{ACKNOWLEDGEMENTS}

My studies of Phoridae are currently supported by a grant from the Balfour-Browne Trust Fund (University of Cambridge). Dr F. Rigato kindly loaned the pin mounted holotype of Gymnophora lapidicola along with three other specimens attributed to this species (Museo Civico di Storia Naturale in Milan).

\section{REFERENCES}

Beyer E. M. 1965: Phoridae (Diptera Brachycera). Exploration du Parc National Albert, Mission G. F. De Witte (1933-1935) 99: 1-211.

BEzzI M. 1922. Un Diptero subattero appartenente ad uno Nuevo gernere di Foridi non myrmecophili. Bollettino della Societa Entomologica Italiana 54: 113-117.

BorgmeIER T. 1959. Neue und wenig bekannte Phoriden aus der neotropischen Region, nebst einigen Arten aus dem Belgischen Congo-Gebiet (Diptera, Phoridae). Studia Entomologica, Petropolis 2: 129-208.

DisNEY R. H. L. 2013. An unusually rich scuttle fly fauna (Diptera, Phoridae) from north of the Arctic Circle in the Kola Peninsula, N. W. Russia. ZooKeys 342: 45-74.

GHIDINi G. M. 1934. Descrizione della femmina di Gymnophora (Capraephora lapidicola Bezzi. Bollettino della Societa Entomologica Italiana 66: 130-136.

Leather S. R., WALters K. F. A. \& BALE J. S. 1993. The Ecology of Insect Overwintering. Cambridge, Cambridge University Press, 255 pp.

MiLLER P. L. 1979. Intraspecific phorid phoresy. Entomologist's Monthly Magazine 114: 211-4 (1978).

Mostovski M. B. \& Disney R. H. L. 2002 (2001). A remarkable new species of Triphleba Rondani (Diptera: Phoridae). Studia dipterologica 8: 557-562.

Mostovski M. B, \& Mikhailovskaya M. V 2003. A review of Palaearctic Gymnophora Macquart (Diptera: Phoridae), with description of new species. European Journal of Entomology 100, 153-165.

SchMITZ H. 1921. Aptinandria, eine neue, in beiden Geschlechtern flügel-und schwingerlose Phoridengattung aus Afrika (Phoridae, Diptera). Entomolgiske Meddelelser 13: 318-22. 
SCHMITZ H. 1958. Acht neue und einige bekannte Phoriden aus Angola und dem Belgischen Kongo (Phoridae, Diptera). Publicaciones Culturais Companhia de Diamantes de Angola (Museu do Dundo Subsídios para o Estudo da Biologia na Lunda) 15: 15-61

\section{STRESZCZENIE}

[Uaktualniony opis górskiego, bezskrzydlego gatunku Gymnophora lapidocola (Bezzi) (Diptera: Phoridae]

W pracy przedstawiono poprawiony i uzupełniony opis gatunku Gymnophora lapidicola (Bezzi, 1922), którego nie tylko samice, ale także samce są bezskrzydłe. Prawdopodobnie, populacje G. lapidicola, zasiedlające różne szczyty górskie, ewoluowały tworząc różne podgatunki lub gatunki bliźniacze.

Accepted: 12 Jun 2015 